\title{
Investigating Determinants of Bay' Salam Financing Product for Agricultural Sector in the Sultanate of Oman
}

\author{
UMAR AHMED* \& BASHIR AHMAD FIDA ${ }^{1}$
}

\begin{abstract}
The purpose of this study is to investigate the determinants of Bay' Salam financing product for the agricultural sector in Oman. A survey is conducted using wellstructured questionnaires to identify the factors that determines viability of Bay Salam financing product for the agricultural sector. The statistical tools used for the analysis are factor analysis and descriptive statistics. The factor analysis results demonstrate that operational costs, profitability and risk mitigation strategies are the most important factors that banks need to take into consideration when financing the agricultural sector using Bay' Salam. Therefore, we suggest that Islamic banks in Oman should adopt Bay' Salam as an alternative Islamic product to finance the agricultural sector. Moreover, the Central Bank is encouraged to allow Islamic banks to adopt this product given that it will assist the government in achieving its 2040 vision.
\end{abstract}

Keywords: agriculture finance, bay' salam, Islamic finance, Islamic financing product, Oman

The Sultanate of Oman has an estimated population of 4.83 million in 2018 based on World Population Review. The Gulf Cooperation Council (GCC) population is expected to increase to more than 50 million by 2020, a drastic rise compared with 41.7 million in 2010. This increase in the GCC population has placed a high demand for food production (Ithraa 2016).

High population growth, increase in the number of tourists and high per capita income are expected to increase food consumption in the region from 54.1 million metric tonnes in 2017 to 60.7 million metric tonnes in 2023. Saudi Arabia and the UAE are expected to remain the largest food consumers with their combined share of approximately 81\%. Oman is expected to experience the fastest annual growth at a CAGR of 4.6\% (Alpen Capital Report 2019).

The demand for imported food in GCC is expected to reach US $\$ 53.1$ billion by 2020 , which is twice the amount of US $\$ 25.8$ billion in the past decade (Ithraa 2016). According to the estimates of the UN's Food \& Agriculture Organization, Oman's food imports will reach US \$4.8 billion by 2020, a drastic increase from US $\$ 2.1$ billion in 2010. Oman's food imports are mainly grains, seasonal fruits, dairy products, poultry and meat. Thus, meeting the expected huge demand for food and developing new opportunities for the agricultural sector to boost domestic production are the challenges faced by the government.

The Sultanate's long coastline and diverse landscapes can support a rich variety of fish, livestock, crops, fruits and vegetables (Ihtraa 2016). Thus, the Oman government initiated numerous policies to ensure long term food security by heavily investing in agriculture, horticulture and fishing. Although government policies are designed to increase food security,

1 Umar Ahmed* (corresponding author), Ph.D, associate professor at Department of Business and Economics, Modern College of Business \& Science Modern, Bawsher Street, P.O. Box 100, Postal Code Alkhuwair 133 MUSCAT, Oman, email: umar.ahmed@mcbs.edu.om; Bashir Ahmad Fida, Ph.D., assistant professor at Modern College of Business and Science, Bawsher Street, P.O. Box 100, Postal Code - Alkhuwair 133 MUSCAT, Oman, email: bashir@mcbs.edu.om. 
the four domestic insurance companies, namely, National Life and General Insurance, Dhofar Insurance, Al-Madina Takaful and Arabia Falcon Insurance Company provide agricultural insurance policies to protect agricultural investors. The policies cover major threats to crops from natural disasters such as floods, natural fires and lightning strikes (Oxford Business Group Report 2019).

Ironically, Islamic banks have yet to provide financing facilities to support the agricultural sector. Likewise, international agricultural sector lacks access to reliable and affordable financing. Financial institutions are reluctant to sanction loans to small-scale farmers due to their inability to provide collateral and the high default risk and high transaction cost associated with small loans (Bhutto \& Bazmi 2007). The only bank that provides a seasonal loan to the agricultural sector in Oman is the Oman Development Bank. Such loan includes the costs of land preparation for agriculture and the purchase of seeds and fertilizers until harvest and marketing. Financing also includes greenhouses. Seasonal loans play a key role in developing the agricultural sector and ensuring maximum food production. Loans that caters to small producers create a link between the production and marketing phases and ensure the continuation of agricultural and fisheries projects (Oman Development Bank 2019). The agricultural sector is part of Oman's 2040 vision blueprint and provides huge opportunities for Islamic banks. Given that some religious farmers may be reluctant to take interest-based loans, Islamic banks can provide them with alternative financing facilities. The need to have Islamic agricultural financing product become a necessity. There are many suggested Bay' Salam models to finance the agricultural sector such as Ogunbado and Ahmad Umar's (2015), Asim and Muhammad's (2015), ISRA (2012), Nida (2013), etc. However, these models are conceptual with hardly any empirical study that investigates the practicality of Bay' Salam as an alternative agricultural financing product. Therefore, this study attempts to fill this research gap by investigating the determinants of Bay 'Salam as an alternative product to finance the agricultural sector in Oman. This study is divided into five sections including introduction. Section two reviews related literature. Section three examines the research method. Section four presents findings and discussions. Section five provides the conclusion of the study.

\section{Literature Review}

\section{Bay' Salam and Its Legality}

Bay' Salam can be directly translated to 'a forward sale'. This term refers to a sale contract whereby a buyer purchases specific commodities that will be delivered by a seller in a future date in exchange for a price that is fully paid in advance (Aburaida 2011). The Bay' Salam contract is used to sell a good that does not exist at the time of the contract. The contract is allowed in Islam, given that meeting the basic needs of farmers is a public interest (Zaabi 2010). Bay' Salam assists small-scale farmers (poor farmers) to have access to financing for agricultural production. Such assistance is needed to improve farmers' standard of living. This contract is also intended to secure the market for farmers, wherein they can sell forward their expected farm products for immediate cash and deliver the product in a specified future date (Kaleem \& Abdul Wajid 2009). Bay' Salam contract is divided into ordinary Salam and parallel Salam. The former involves a financier and a farmer, whereas the latter is a contractual arrangement that consists of two different and independent Bay' Salam contracts one in which the bank is a buyer and the other in which the bank is a seller' (ISRA 2012).

This contract is legal based on evidence from the Quran, Sunnah and Ijma. Ibn Abbas commented that: 'I bear the witness that al-Salaf (Al-Salam) stipulated for a stated term is made legal by Allah' in this verse [2:282] from Qur'an. Before the prohibition of interest, farmers used to file for interest-based loans for agricultural production. However, after the prohibition of interest-based loans, small-scale farmers find it difficult to access financing. Therefore, Bay' Salam 
provides alternatives wherein the Prophet (P.B.U.H) has allowed farmers to be fully paid in advance for crops that will be delivered in the future. Ibn Abbas has also added that people of Medina used to practice Bay' Salam, wherein farmers are paid in advance for fruits that will be delivered in a future date. This practice has been allowed by the Prophet. During the time of the Prophet Muhammad (P.B.U.H), Bay' Salam is initially used for dates, barley, wheat and grapes, then olives and dry grapes are later included. The exact date and place of delivery must be specified in the contract. The minimum time duration for the delivery of Bay' Salam product is 15 days. However, the delivery date depends on the date agreed upon by contracting parties, wherein the goods must be delivered based on the agreed date. Bay'Salam contract is terminated if one of the contracting parties dies, mutual consent is given to cancel the contract and the subject matter is destroyed (Al-Zuhayli 2007).

\section{Agricultural Sector in Oman}

Agriculture is the art and science of growing plants and crops and raising livestock for food and other human needs or economic gain as in www.cropreview.com. Agriculture plays a vital role in the development of human civilisation, whereby mass production of agricultural goods facilitates urbanisation where people can live comfortably in cities and enjoy a variety of food. Agricultural sustainability provides food security, protects the environment and increases farmers' income, improving their standard of living (Hendriks \& Lyne 2009).

Agriculture and fisheries are the backbone of Oman's economy and exhibit a deep-rooted cultural significance. Before the discovery of oil in the 1960s, $80 \%$ of the population have depended on agriculture and fishing industry (World Bank 2015). However, in the 1970s onwards, this sector becomes less important due to over-reliance on the oil sector. The fall in oil prices and concerns over food security have compelled the government to revive the agricultural and fishery sector. In Oman, agricultural production constitutes mainly dates, vegetables, fruits and grains, such as wheat and barley in small quantities. Oman is famous for producing highquality agricultural goods, which are mostly exported to neighbouring GCC countries. Over the past decades, Oman has increased domestic food production from 1.2 million tonnes in 2008 to 2.6 million tonnes in 2017. Vegetable, fruits and grains' production has accounted for 814,570 tonnes, 450,819 tonnes and 18,943 tonnes, respectively. The country's self-sufficiency in food has increased to $80 \%$. The dairy production is expected to reach 96,000 tonnes in 2020, bringing dairy sufficiency to $67 \%$ in 2020. Poultry and meat self-sufficiency is expected to reach 46\% and 44\%, respectively, in 2020 (Oxford Business Group Report 2019).

According to the Oxford Business Group Report, food security is the core aspect of Oman's agricultural policy due to fluctuation in global food prices and fall in oil prices. Oman's economic development policies emphasise economic diversification in agricultural, fishery, industrial and mining sectors to reduce dependence on oil exports. Agricultural modernisation and rural farm development are the key pillars of the Oman Ministry of Agriculture and Fisheries' Sustainable Development 2040 Strategy, which is part of the Oman Vision 2040. In line with this vision, the government has established the Oman Food Investment Holding Company to develop, invest in and implement programmes aimed at boosting farm production and food processing. Such programmes are focused on increasing exports of dates, honey, fruits and vegetables, dairy and egg production and red meat (Oman Agrofood 2019). Under the government's 8th Five-Year Economic Development Plan (2011-2015), Oman invested US $\$ 4.941$ billion in a variety of agriculture- and fisheries-related infrastructure projects to upgrade existing facilities. Agriculture and fisheries grew by 7\% in 2018 with a total value of $\$ 1.4$ billion, accounting for $2 \%$ of the overall GDP and its expected to increase to above 3\% of the GDP in 2020. Despite its relatively small contribution to GDP, the sector is nonetheless important to the economy, employing $4.5 \%$ of all private-sector jobs in 2017 and guaranteeing long term food security (Oman Agrofood 2019). 


\section{Bay' Salam Models for Agricultural Financing}

Scholars have proposed several Bay' Salam models for the financing of the agricultural sector. In ISRA (2012) model, Islamic banks can enter into two independent parallel Bay'Salam: one with a farmer to buy agricultural products that will be delivered in the future and a Salam contract with wholesaler or broker to sell the product obtained from farmers. Then, a bank will buy the commodity at a lower price from farmers and sell the same commodity at a higher price to a wholesaler or broker. The difference between the two prices would constitute the bank's profit. The shorter the time left to maturity, the higher would be the price. However, both transactions should be independent of each other. The original transaction should not have been priced to do a subsequent parallel Salam.

Ogunbado and Ahmad Umar's (2015) model is similar to the above model. Their model is based on parallel Bay' Salam contract whereby farmers will contract financiers which can be an Islamic bank or Islamic cooperative society to sell a specific quantity and quality of agricultural products that will be delivered at a specified future date. Then, a financier will pay farmers a full amount in advance. Upon the harvest of the crop, the financier will enter into another Bay'Salam contract with wholesalers and promise to supply them with specified agricultural products at a specific date for a competitive market price. Upon the delivery of the products by farmers, the financier will immediately sell the products to the wholesalers at an agreed price.

In Nida's (2013) model, a farmer will apply for an agricultural finance facility from an Islamic bank and provides complete specification of the crops, selling price, costs of production, production yield and date and place of delivery. The bank through its agricultural experts will cross-check the information to ensure that they are accurate. Upon approval of the financing, the Islamic bank will ask the customer to sign the Master Salam Agreement that includes all the terms and conditions of Bay'Salam. The Islamic bank may also ask the farmer to be its agent and sell the crop to the market once it is harvested. However, the sales' contract and the agent's contract should be parallel. The Islamic bank must pay the full price to a farmer in advance by crediting the amount in his account. Upon the time of harvest, the farmer will deliver the crops to the bank. Once the bank physically possesses the crop, the bank will then ask the farmer to sell the crop in the market for a higher price based on the Agency Agreement (Amjad 2016).

Asim and Muhammad's (2015) model has suggested that the contract involves a farmer and financier whereby the farmers sell the agricultural product to the financier. The farmer applies for agricultural financing to grow a crop, e.g. wheat. The financing will cover the entire three production periods, i.e. cultivating, seedling and harvesting periods, which will take approximately five to six months. Financier, which can be a company, a bank or any other institution, hires an inspection team (i.e. agricultural specialists) who will inspect the land and estimate its production capacity. Based on their report, the quantity, quality and date of delivery will then be specified in the Salam contract. This estimate of production capacity is calculated based on the previous average production per acre of land in the same area. Then, the financier will hire economic experts to forecast the price of wheat upon harvest, i.e. five months. Historical data will be used to provide an estimate of the expected future prices. At the time of signing Salam financing contract, quantity, quality, date of delivery and price should be specified. Farm's land can be used as collateral to reduce default risk. To avoid moral hazard, an agricultural specialist will visit the farm regularly to ensure timely delivery. Visits from an agricultural specialist ensure certainty in terms of delivery quality product within a specified timeframe. Upon the time of delivery, the financier can either hire an agent or use the services of the farmers to sell the goods on his behalf to the wholesalers or millers. Alternatively, the financier can either appoint miller or wholesalers as an agent and sell the product or create distribution channel to sell the product. 


\section{Proposed Bay'Salam Model for the Financing of the Agricultural Sector in Oman}

The proposed Bay' Salam model for the financing of the agricultural sector in Oman is adopted from Ogunbado and Ahmad Umar's (2015) and Asim and Muhammad's (2015) models with little modification. Figure 1 below shows the proposed model.

Figure 1: Proposed Bay' Salam Model for the Financing of the Agricultural Sector in Oman

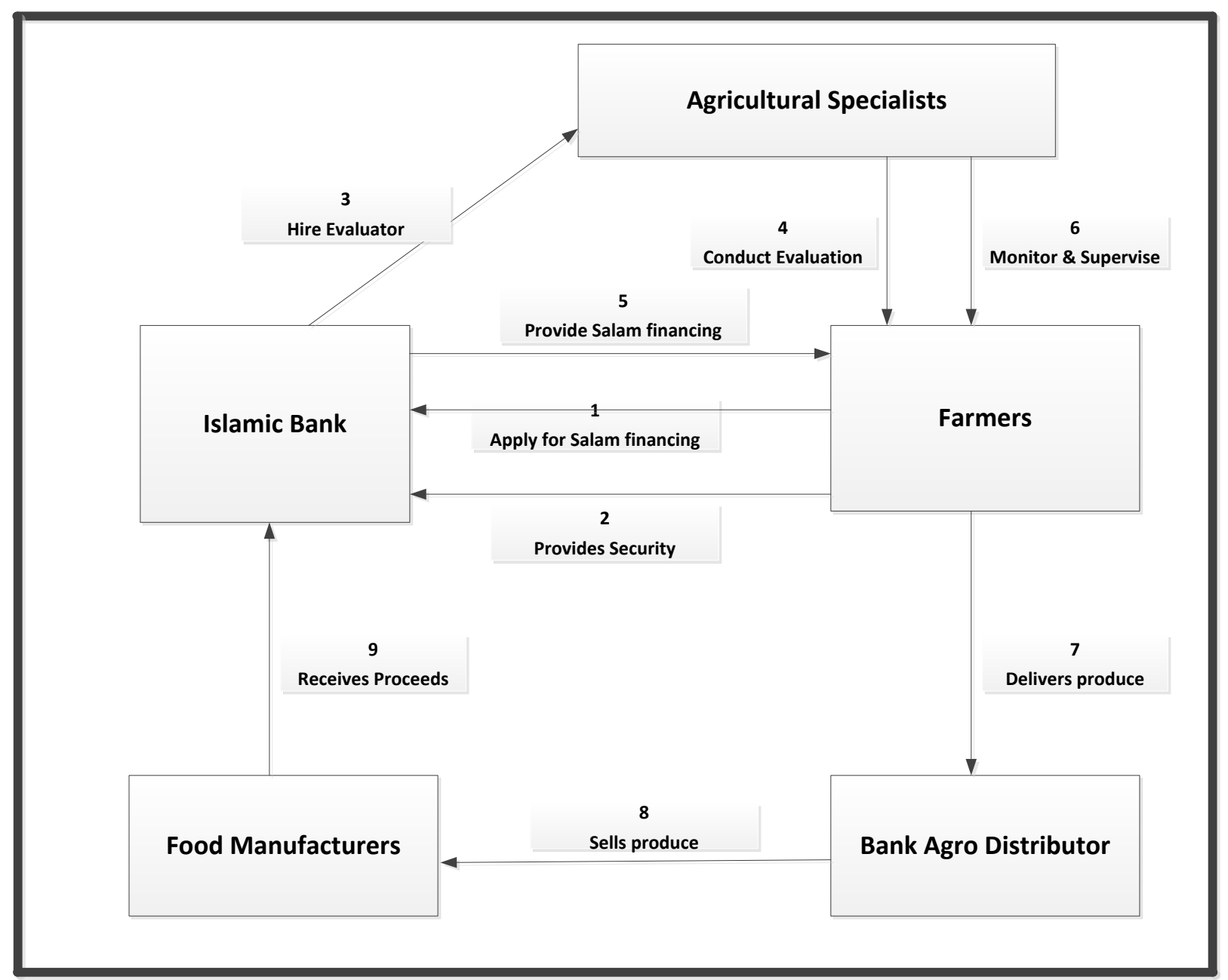

In Figure 1, the Islamic bank enters into two (parallel) Bay' Salam contracts: one with farmers to provide financial support and a Salam contract with a food manufacturer to sell its agricultural products. The process for financing is as follows: firstly, the farmers will request an agricultural financing from an Islamic bank for specified crops based on Bay' Salam contract. Secondly, upon the request acceptance, the Islamic bank will ask the farmer to sign a master agreement and request for collateral from the farmers. The collateral can be the farmland. The collateral is used to reduce the non-delivery or default risk. Thirdly, the Islamic bank will hire agricultural specialists who will inspect the land, estimate its production capacity, determine its quality, quantity and production period and forecast prices based on historical data. The specialists will conduct proper forecasting and fix future prices for the product to mitigate market risk. Based on their report, the quantity, quality, date of delivery and price will then be specified in the terms and conditions of the Salam contract. Fifthly, the Islamic bank will provide financing for agricultural products based on three stages, i.e. beginning (cultivation and seeding), middle 
(fertilizer time) and end (harvesting time) seasons of farming based on the agreement. Sixthly, agricultural specialists will monitor the progress of agricultural production within the three stages, given that the financing will be released based on the progress made in each stage. This process will help mitigate the problem of moral hazards. Before the delivery date of the agricultural products, the Islamic bank will contact the food manufacturer through its agro distributor and sell the consignment at a competitive price. Seventhly, once the agro bank distributor receives the consignment from the farmers, the distributor will immediately deliver the products to the food manufacturer. Lastly, the bank will receive payment from the manufacturer based on their agreement.

\section{Research Method}

In order to investigate the practicality of the proposed Bay Salam models, the study used a survey to seek the opinion of Islamic banks' employees in the product development department on the models. The respondents were asked on the concept, application and implications of Bay Salam as an alternative financing product for the agricultural sector in Oman. Survey research is a descriptive approach that is used to collect information from or about people to describe, compare, or explain their knowledge, feelings, values, and behavior (Sekaran \& Bougie 2016). In a survey, researchers are able to collect original data to describe a population that is too large to observe directly (Lacobucci \& Churchill 2010). Moreover, the method is suitable for collecting data about attitudes and opinions (Burns \& Bush 2000). The study has identified three measurable variables from the proposed models to develop a research instrument. These variables include concept, application, and the implication of Bay Salam as a financing product. Pilot testing was conducted to measure the reliability and validity of the instrument. Malhotra and Birk (2007) suggested that the draft of the questionnaire needs to be evaluated and checked by a group of people at the pilot testing stage prior to the actual distribution. Cronbach's Alpha was used to test for the reliability of the instrument. According to (Sekaran \& Bougie 2016) the closer Cronbach's alpha is to 1 , the higher the internal consistency and reliability. Table 1 illustrates the measurable variables and the reliability of the instrument.

Table 1. Measurements of the Questionnaire \& Reliability Result

\begin{tabular}{|c|c|c|c|c|}
\hline Variables & No. of Questions & Items & Source & $\begin{array}{l}\text { Measurement } \\
\text { Scale } \\
\text { Reliability }\end{array}$ \\
\hline $\begin{array}{l}\text { Demographic } \\
\text { Factors }\end{array}$ & $1-5$ & 5 & Self-created & Nominal Scale \\
\hline Concept & $1-6$ & 6 & ISRA (2012) & $\begin{array}{l}\text { Likert scale } \\
\text { measurement } \\
0.893\end{array}$ \\
\hline Application & $1-7$ & 7 & Ogunbado \& Umar (2015) & $\begin{array}{l}\text { Likert scale } \\
\text { measurement } \\
0.819\end{array}$ \\
\hline Implication & $1-8$ & 8 & $\begin{array}{c}\text { Asim \& Muhammed (2015). } \\
\text { Nida ( 2013) }\end{array}$ & $\begin{array}{l}\text { Likert scale } \\
\text { measurement } \\
0.751\end{array}$ \\
\hline All variables & & 21 & & 0.814 \\
\hline
\end{tabular}

Well-structured questionnaires which consistent of four sections based on each variable are distributed to a sample of 100 employees who are working in the product development department of Islamic banks in Oman using a convenient sampling technique. The response rate 
was $80 \%$. SPSS software is used for data analysis. Factor analysis and descriptive statistics are statistical tools used in data analysis. Factor analysis is used to identify factors that will influence the decision of Islamic Banks to apply Bay' Salam as a product to finance the agricultural sector in the Sultanate. According to Vaus (2002), factor analysis is suitable to use when factors are not single measurable entities but are constructs of several other directly observable variables. Thus, the analysis can cluster observable variables into factors, wherein each factor reflects an underlying property that is commonly shared by a certain group of variables. The Kaiser-MeyerOlkin (KMO) and Bartlett's test of sphericity are used to test the factorability of the data. The former measures sampling adequacy, whereas the latter is a test of sphericity. Kaiser (1974) has suggested that a KMO measure can have the following values: above 0.9 (sample is 'marvellous'), 0.80-0.89 (sample is 'meritorious'), 0.70-0.79 (sample is 'middling'), 0.50-0.59 (sample is 'miserable') and less than 0.50 (sample is 'unacceptable'). For the factor analysis to proceed, Bartlett's test of sphericity should be significant $(p<0.05)$ (Vaus, 2002). Vaus has added that the interpretation of factors is based on the loadings of variables of these factors. An item belongs to the factor if it has high loading.

\section{Findings and Discussion}

According to Table 1, the majority of the respondents are male (72\%), and only $28 \%$ are female. A total of $74 \%$ have ages ranging from 31 to 40 years, and $12 \%$ are above 40 years. The overwhelming majority are married (94\%), degree-holders (86\%) and have more than five years of working experience (81\%) in Islamic banks in Oman. The opinions expressed in the survey reflect the attitudes and perceptions of a middle-aged male, married, and degree-holder respondents.

Table 2: Demographic Profile of Respondents

\begin{tabular}{|l|l|r|r|}
\hline \multicolumn{2}{|l|}{ Demographic Information } & Frequency $n=72$ & Percentage \\
\hline Gender & Male & 52 & 72 \\
& Female & 20 & 28 \\
\hline Age & $20-30$ & 10 & 14 \\
& $31-40$ & 53 & 74 \\
& Above 40 & 9 & 12 \\
\hline Marital status & Single & 4 & 6 \\
& Married & 68 & 94 \\
\hline Education & Professional & 2 & 3 \\
& Graduate & 62 & 86 \\
& Postgraduates & 8 & 11 \\
\hline Experience & Less one year & 2 & 2 \\
& 1-5 years & 12 & 17 \\
& Above 5 years & 58 & 81 \\
\hline
\end{tabular}

Factor Analysis Result

Factor analysis is conducted to determine the most important factors that will influence the decision of Islamic bankers to adopt Bay' Salam to finance the agricultural sector in Oman. KMO and Bartlett's test of sphericity are used to test the factorability of the data (Vaus 2002). Table 2 shows the results. 
Table 3: KMO and Bartlett's Test Results

\begin{tabular}{|l|l|r|}
\hline KMO Measure of Sampling Adequacy & 0.834 \\
\hline Bartlett's Test of Sphericity & Approx. Chi-Square & 235.529 \\
& Df & 235.529 \\
& Sig. & 0.000 \\
\hline
\end{tabular}

As shown in Table 3, the KMO measure of sampling adequacy is 0.834 . This finding indicates that our sample is 'meritorious' based on Kaiser's (1974) scale, and therefore appropriate to be used for factor analysis. This finding is supported by Bartlett's Test of Sphericity which is also statistically significant (0.000) for the factorability of the correlation matrix. Principal Component Analysis (PCA) and Varimax rotation with Kaiser Normalisation are conducted. Factors are extracted from items using PCA with an eigenvalue greater than 1.0. The results identify the three most important factors with several high factor loading. Although factor loadings of 0.30 to 0.40 are minimum requirements for factorability, values greater than 0.5 are desirable for practical significance (Hair et al., 2014). Communalities measure correlations among the fifteen items to be tested with factor analysis. The higher the correlations among the variables, the higher would be their communalities. In Table 3, three factors with eigenvalues greater than $1(3.18,2.16$ and 1.25) are observed. This initial analysis, therefore, resulted in a three-factor solution. Specifically, 10 items are reduced to three factors. Each factor explains a certain percentage of variance. In this case, factors 1, 2 and 3 explain 41\%,32\% and 22\%, respectively. In sum, these three factors explain a total of $95 \%$ of the variance.

Table 4: Rotated Component Matrix on Determinants of Application of Bay' Salam in the Agricultural Sector

\begin{tabular}{|c|c|c|c|c|}
\hline \multirow[b]{2}{*}{ Items } & \multicolumn{3}{|c|}{ FACTOR } & \multirow[b]{2}{*}{$\begin{array}{l}\text { Communality of } \\
\text { Each Variable }\end{array}$} \\
\hline & $\begin{array}{c}1 \\
\text { Operational } \\
\text { Cost }\end{array}$ & $\begin{array}{c}2 \\
\text { Profitability }\end{array}$ & $\begin{array}{c}3 \\
\text { Risks Mitigation }\end{array}$ & \\
\hline $\begin{array}{l}\mathrm{X} 1 \\
\mathrm{X} 2 \\
\mathrm{X3} \\
\mathrm{X} 4 \\
\mathrm{X6} \\
\mathrm{X} 7 \\
\mathrm{X} 8 \\
\mathrm{X} 9 \\
\mathrm{X} 10\end{array}$ & $\begin{array}{l}0.826 \\
0.681 \\
0.796 \\
0.616\end{array}$ & $\begin{array}{l}0.850 \\
0.741 \\
0.763 \\
.\end{array}$ & $\begin{array}{l}0.804 \\
0.483\end{array}$ & $\begin{array}{l}0.742 \\
0.538 \\
0.688 \\
0.639 \\
0.646 \\
0.752 \\
0.656 \\
0.599 \\
0.710 \\
0.544\end{array}$ \\
\hline Eigenvalues & 3.107 & 2.161 & 1.245 & \\
\hline$\%$ of variance & 41.073 & 31.612 & 22.448 & \\
\hline Cumulative \% & 41.073 & 72.685 & 95.133 & \\
\hline
\end{tabular}

Extraction Method: Principal Component Analysis.

Rotation Method: Varimax with Kaiser normalisation. 


\section{Discussion}

The findings empirically identified the three most important factors that will influence the decision of Islamic banks to adopt Bay' Salam to finance the agricultural sector. These factors include operational costs, risk mitigation strategies and profitability. According to the findings, Islamic banks can apply Bay' Salam to finance the agricultural sector in Oman only if the operational costs are low, effective risk mitigation strategies are present and the product is profitable to Islamic banks. Asim and Muhammad (2015) model suggests that Islamic banks need to hire agricultural specialists who will inspect the land and estimate its production capacity, the economist to forecast the price of the Salam crop based historical data to determine sale price and sale agent to sell the goods on behalf of an Islamic bank to the wholesalers or millers. Alternative, the financier can appoint miller or wholesalers as an agent \& sell the product, or it can create its distribution channel to sell the produce. In deed, hiring many agents in this respect can raise the operational cost and make the Salam financing product not feasible. In nutshell, Islamic banks can adopt this model only if the operational costs are low, otherwise it will be less attractive to bankers.

Islamic banks can provide access to Bay' Salam financing if certainties in market conditions and prices in which Islamic banks can earn a profit are present. Otherwise, bankers will obtain less incentives from availing such product. According to Asim and Muhammad( 2015) to create price certainty, economists are hired to forecast the price of the produce upon harvest based on historical data. Risk mitigation strategies are also crucial in the model viability. Salam financing exposes Islamic banks to credit risk, market risk and moral hazard. To reduce credit risk Islamic banks can request collateral from the farmers, wherein the farmland can be used as mortgage security. Collateral and mortgage security will reduce non-delivery/credit risk. Agricultural specialists should conduct proper forecasting and fix future prices for the product to mitigate market risks. Agricultural specialist will monitor the progress of agricultural production on three stages, given that the financing will be released based on the progress made in each stage. This process will help mitigate the problem of moral hazards (Asim \& Muhammad 2015). The findings reveal that effective risk mitigation strategies are crucial for Islamic banks to adopt Bay' Salam as financing products for the agricultural sector in the Sultanate.

To conclude, Oman is heavily dependent on food imports, which is unsustainable. Such unsustainability exposes the country to inflation of imported products and trade imbalances. Therefore, sustainable development in the agricultural sector would increase agriculture's contribution to the GDP, reduce the number of imported products and provide food security. Given that agriculture is a key component of Oman 2040 vision, Bay' Salam could provide Islamic financing alternatives to the agricultural sector in the Sultanate. Our findings reveal that Islamic banks can adopt Bay' Salam to finance the agricultural sector in Oman, but only if the operational costs of financing are low, the product is profitable and the bank can mitigate risks effectively. Introducing a product is viable. Therefore, we suggest that Islamic banks should diversify their products by introducing Bay' Salam financing facility for the agricultural sector in the Sultanate.

\section{References}

The Holy Quran, Original Arabic Text with English Translation \& Selected Commentaries. 2004. Trans. Abdullah Yusuf Ali. Kuala Lumpur: Saba Islamic Media.

Aburaida, K. M. M. 2014. Rural finance as a mechanism for poverty alleviation in Sudan, with an emphasis on salam mode. European Scientific Journal 7(26): 57-166.

Alpen Capital Report. 2019. Revealed: how much more food the GCC will consume by 2023. Arabian Business, September. (online) https://www.arabianbusiness.com/retail/ 427711-revealed-how-much-more-food-the-gcc-will-consume-by-2023 [23 December 2019]. 
Amjad Bangash. 2016. Practical Applications of Salam Mode of Islamic Finance in an Agricultural Perspective. (online) https://www.linkedin.com/pulse/practical-applications-salammode-islamic-finance-amjad-bangash [23 December 2019].

Asim Ehsan \& Muhammad Asghar Shahzad. 2015. Bay salam: a proposed model for shari'ah compliant agriculture financing. Business \& Economic Review 7(1): 67-80.

Bhutto, W. A. \& Bazmi, A. A. 2007. Sustainable Agriculture and Eradication of Rural Poverty in Pakistan. London: Blackwell Publishing.

Burns, A.C \& Bush, R.F. 2000. Marketing Research. London: Prentice-Hall.

Hendriks, S. L., \& Lyne, M. C. (ed.). 2009. Does Food Security Improve when Smallholders Access a Niche Market? Lessons from the Embo Community in South Africa. South Africa: The African Centre for Food Security, University of KwaZulu-Natal.

ISRA. 2012. Islamic Financial System: Principles and Operations. Kuala Lumpur: International Shari'ah Research Academy for Islamic Finance.

Ithraa: The Public Authority for Investment Promotion \& Export Development Report. 2016. Sultane of Oman, December. (online) https://ithraa.om/portals/0/IthraaPDF/Brochures/PDF/ ithraa_briefing_agriculture_eng_AW.pdf [28 September 2019].

Kaiser, Henry F. 1974. An index of factorial simplicity. Psychometrika 39(1): 31-36.

Kaleem, A. and Abdul Wajid, R. 2009. Application of Islamic banking instrument (bay salam) for agriculture financing in Pakistan. British Food Journal 111(3): 275-292.

Lacobucci, Dawn \& Churchill, Gilbert A. 2010. Marketing Research: Methodological Foundations. South-Wester: Cengage.

Malhotra, N. K \& Birks, D. F. 2007. Marketing Research an Applied Approach. 3rd European eds. Harlow: Pearson Education Limited.

Nida Khan. 2013. Designing an Islamic financial product. Dessertation Master Diploma in Islamic Finance, AIMS, UK.

Ogunbado, A.F. \& Ahmed, U. (2015). Bay' Salam as an Islamic financial alternative for agricultural sustainability in Nigeria. Journal of Islamic Economics, Banking, and Finance 11(4): 63-75.

Oman Agrofood. 2019. Oman's Market Insights, n.d. Oman Agrofood (online) http://www.omanagrofood.com [10 January 2020].

Oman Development Bank. 2019. Who are We? Products and Services. Oman Development Bank, n.d. (online) https://odb.om/public/uploads/Bruchor.pdf [11 January 2020].

Oxford Business Group Report. 2019. Oman looks to increase food security by boosting domestic production and sharing up the supply chain. Oxford Business Group, n.d. (online) https://oxfordbusinessgroup.com/overview/cultivating-sustainability-initiatives-lookincrease-food-security-boosting-domestic-produce-and [10 January 2020].

Sekaran, Uma \& Bougie, Roger. 2016. Methods For Business: A Skill Building Approach. 7th Eds. USA: John Willey and Son Inc.

Vaus, D. A. 2002. Analysing Social Science Data. London: Sage Publications.

World Bank. 2015. Sustainable Management of the Fisheries Sector in Oman: A Vision for Shared Prosperity. World Bank Advisory Assignment, December. (online) http://documents.worldbank.org/curated/en/901371480601979449/pdf/110678WP-Summary-Oman-Fisheries-PUBLIC.pdf [16 November 2019].

World Population Review: Oman Population 2018. (online) https://worldpopulationreview.com/ [10 January 2020].

Zaabi, S. O. 2010. Salam contract in Islamic law: a survey. Review of Islamic Economics 14(2): 91122.

Al-Zuhayli, Wahbah. 2007. Financial Transactions in Islamic Jurisprudence. Trans. Mohamoud A. el-Gamal. Beirut: Dār al-Fikir al-Mu'āṣir. 